\title{
Knowledge and Awareness of Role of Endodontics in Forensic Odontology- A Questionnaire Based Survey among Postgraduate Students
}

\author{
Yalla R. S. Susmitha ${ }^{1}$, Mahalaxmi Yelapure², Mithra N. Hegde³, Darshana Devadiga ${ }^{4}$, Upasana Reddy ${ }^{5}$ \\ ${ }^{1}$ Department of Conservative Dentistry and Endodontics, A. B. Shetty Memorial Institute of Dental Sciences, Mangalore, \\ Karnataka, India. ${ }^{2}$ Department of Conservative Dentistry and Endodontics, A. B. Shetty Memorial Institute of Dental \\ Sciences, Mangalore, Karnataka, India. ${ }^{3}$ Department of Conservative Dentistry and Endodontics, A. B. Shetty Memorial \\ Institute of Dental Sciences, Mangalore, Karnataka, India. ${ }^{4}$ Department of Conservative Dentistry and Endodontics, A. B. \\ Shetty Memorial Institute of Dental Sciences, Mangalore, Karnataka, India. ${ }^{5}$ Department of Conservative Dentistry and \\ Endodontics, A. B. Shetty Memorial Institute of Dental Sciences, Mangalore, Karnataka, India.
}

\section{ABSTRACT}

\section{BACKGROUND}

The unique nature of human teeth has always been a special aid in personal identification throughout history.[1] Forensic odontology is a branch of dentistry that deals with the application of dental knowledge to those criminal and civil laws that are enforced by the investigative agencies in a criminal justice system.2] Dental tissues are the strongest tissues in the human body and therefore their characteristics remain unchanged even in extreme environment and can survive long periods in conditions like burial under soil, fire and exposure to any biological agents in the environment.[3] Therefore, the importance of teeth in forensics is profoundly increasing. Endodontics in particular plays a pivotal role in forensic investigation by providing adequate knowledge of root canal anatomy, periapical radiographs, dental restorations, which favour comparison and personal identification of a deceased person.[1] We wanted to evaluate the knowledge and awareness of the role of endodontics in forensic odontology among postgraduate students enrolled in the specialty of Conservative Dentistry and Endodontics.

\section{METHODS}

A standardized web-based questionnaire survey was conducted in a group of post graduate students $n=306$ (endodontists) in which 20 questions related to the role of endodontics in forensic odontology were included. The responses were recorded, and the data was analyzed using statistical analysis. Based on the responses obtained, data was analysed, and the frequencies and percentages were calculated.

\section{RESULTS}

The results of the present survey revealed that $6 \%$ of total participants had good awareness (>16 Qs), $62 \%$ of total participants showed moderate awareness (10-16 Qs) and $32 \%$ of total participants had poor awareness ( $<10 \mathrm{Qs})$.

\section{CONCLUSIONS}

This survey was conducted to assess the knowledge and awareness on practical usefulness of endodontics in forensic odontology. By considering the present expansion in field of forensic odontology, endodontists should be knowledgeable of the role and importance of their specialization in personal identification.

\section{KEY WORDS}

Age Estimation, Endodontics, Forensic Odontology, Pulpal DNA, Restorative Materials
Corresponding Author: Dr. Mahalaxmi Yelapure, Department of Conservative Dentistry and Endodontics, A. B. Shetty Memorial Institute of Dental Sciences, Deralakatte, Mangalore-575018, Karnataka, India.

E-mail: drmahalaxmipatil@gmail.com

DOI: 10.14260/jemds/2020/59

Financial or Other Competing Interests: None.

How to Cite This Article:

Susmitha YRS, Yelapure M, Hegde MN, et al. Knowledge and awareness of role of endodontics in forensic odontology- a questionnaire based survey among postgraduate students. J. Evolution Med. Dent. Sci. 2020;9(05):262-265, DOI: $10.14260 / \mathrm{jemds} / 2020 / 59$

Submission 15-12-2019, Peer Review 14-01-2020, Acceptance 20-01-2020, Published 03-02-2020. 


\section{BACKGROUND}

The unique nature of human teeth has always been a special aid in personal identification throughout history. [1] Forensic odontology is a branch of dentistry that deals with the application of dental knowledge to those criminal and civil laws that are enforced by the investigative agencies in a criminal justice system.[2] Forensic dentistry involves the presentation of dental evidence with the purpose of contributing scientific and objective data in legal processes. ${ }^{[4]}$ Dental tissues are the strongest tissues in the human body and therefore their characteristics remain unchanged even in extreme environment and can survive long periods in conditions like burial under soil, fire and exposure to any biological agents in the environment.[3] Therefore, the importance of teeth in forensics is profoundly increasing.

The identification of victims of incineration events is an intensive task that requires multi-disciplinary approach. SEM has been used in forensic dentistry to analyse severely burnt and fragmented teeth as it allows sufficient magnification, distinct surface changes in the hard tissues. It can also provide detailed information such as markings from a dental drill, when used under very high resolution. ${ }^{[4]}$ The status of a person's teeth changes throughout life and the combination of decayed, missing, and filled teeth is measurable and comparable at any fixed point in time.[1] Age is one of the essential factors in establishing the identity of a person.[5] And also, the presence of middle mesial canals, multiple canals in teeth help in personal identification. The application of 3D technological advances provides a more accurate method for age determination, and assessment of the root and root canal morphology for forensic identification. ${ }^{[1]}$

An endodontically treated tooth potentially contains more individuating information than a non-endodontically treated tooth and also is a good source of comparative image data. ${ }^{[4]}$ Because, endodontically treated teeth contain root canal filling materials such as gutta-percha, silver points, root canal sealers in addition to metallic and fiber posts, and post endodontic coronal restorations. ${ }^{[1]}$ Quantification of any pulpdentin complex morphological changes nearly or always requires extraction and sectioning of teeth, which is unethical to be done in living individuals. Therefore, techniques developed for age estimation in living individuals mostly rely on radiological imaging of teeth. Post-mortem radiograph taken in a way that it duplicates the ante-mortem radiograph is extremely useful in the comparison process for personal identification and also visual comparison of pairs of corresponding radiographs may be thought of as a patternmatching exercise. In recent years, micro-computed tomography (micro-CT) has gained increasing significance in the study of root canal morphology in endodontics.[4]

Intracoronal restorations, such as amalgam and resin composite fillings, can also maintain their integrity at elevated temperatures.[6] Tooth being an excellent source of DNA i.e. the pulpal DNA. DNA extraction can be considered as one of the methods to identify a person in crime scenes, mass disasters etc. One study showed that DNA extraction can be successful even after 3 months of pulp extirpation.[7] Therefore, Endodontics in specific plays a pivotal role in forensic investigation by providing adequate knowledge of root canal anatomy, periapical radiographs, dental restorations, which favors comparison and personal identification of a deceased person. And this survey focused mainly on the practical usefulness of endodontics in various possible ways of human identification. ${ }^{[4]}$

\section{METHODS}

The present study included 306 postgraduates pursuing the specialty of Conservative Dentistry and Endodontics in different parts of India. A standardized web-based questionnaire survey comprising 20 questions was prepared. The Institutional Ethical clearance was obtained (cert. No: ABSM/EC 19/2019).The questions were designed pertaining to basic knowledge of forensic odontology, knowledge of root canal anatomical variations and its significance in dental records, properties of endodontic materials, pulpal DNA, radiographic methods, age estimation methods, etc. were included in the questionnaire. The responses obtained for each question were recorded and the frequencies and percentages were calculated to assess the knowledge and awareness among the participants.

\section{Statistical Analysis}

The sample size was calculated considering $80 \%$ power. The responses were recorded, and the data was analyzed using statistical analysis. Based on the responses obtained, data was analysed, and the frequencies and percentages were calculated.

\section{RESULTS}

The results showed the percentage of right and wrong answers for each question and overall awareness percentage of the postgraduate students pertaining to the role of endodontics in forensic odontology. The Responses were Recorded and Tabulated.

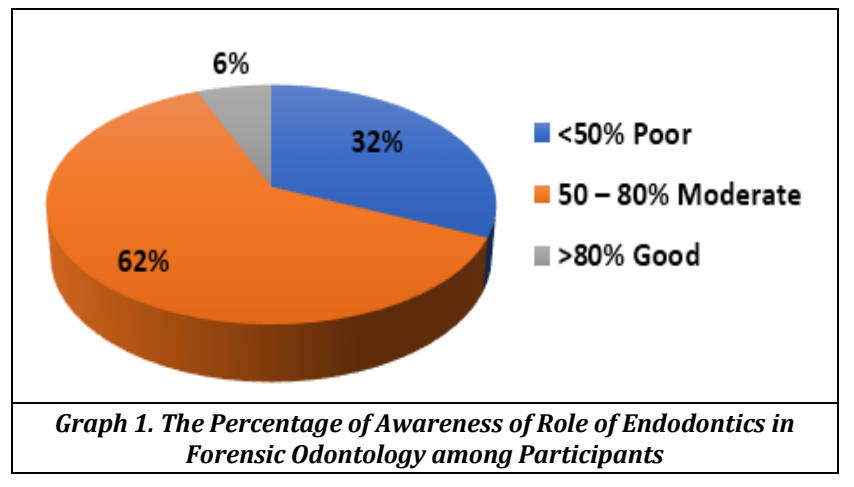

\section{DISCUSSION}

The present survey aimed to gain an insight about the knowledge and awareness of role of endodontics in forensic odontology. It was conducted among the post graduate students in the specialty of Conservative Dentistry and Endodontics to assess the awareness and the knowledge 
about role of endodontics and the various materials used to restore the teeth in identification of a deceased person.

\begin{tabular}{|c|c|c|c|c|c|}
\hline \multirow[b]{2}{*}{$\begin{array}{l}\text { Sl. } \\
\text { No. }\end{array}$} & \multirow[b]{2}{*}{ Questions } & \multicolumn{2}{|c|}{ Wrong } & \multicolumn{2}{|c|}{ Right } \\
\hline & & 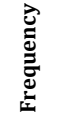 & de & 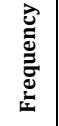 & o \\
\hline 1 & $\begin{array}{l}\text { Which among the following is an important and } \\
\text { resort for personal identification in mass disasters? }\end{array}$ & 50 & 16.3 & 256 & 83.7 \\
\hline 2 & $\begin{array}{l}\text { What is the total percentage of dental identifications } \\
\text { that could be done through dental evidence? }\end{array}$ & 223 & 72.9 & 83 & 27.1 \\
\hline 3 & $\begin{array}{l}\text { Which of the following aids in comparatively better } \\
\text { identification of a deceased person through forensic } \\
\text { odontology? }\end{array}$ & 85 & 27.8 & 221 & 72.2 \\
\hline 4 & $\begin{array}{l}\text { What Is the Most common and reliable Index used In } \\
\text { Forensic Odontology? }\end{array}$ & 93 & 30.4 & 213 & 69.6 \\
\hline 5 & $\begin{array}{l}\text { There are certain Intracoronal restorative materials } \\
\text { like amalgam and composites, gutta-percha, root } \\
\text { canal sealers, which can sustain higher } \\
\text { temperatures. Do you agree? }\end{array}$ & 144 & 47.1 & 162 & 52.9 \\
\hline 6 & $\begin{array}{l}\text { What is the maximum temperature that could be } \\
\text { sustained by amalgam, composites, root canal } \\
\text { sealers, gutta-percha (in Celsius) }\end{array}$ & 281 & 91.8 & 25 & 8.2 \\
\hline 7 & $\begin{array}{l}\text { Which among the following is the most reliable } \\
\text { source of antemortem evidence in human } \\
\text { identification in dentistry? }\end{array}$ & 215 & 70.3 & 91 & 29.7 \\
\hline 8 & $\begin{array}{l}\text { What is the method that is used to compare } \\
\text { antemortem and post-mortem radiographs? }\end{array}$ & 81 & 26.5 & 225 & 73.5 \\
\hline 9 & $\begin{array}{l}\text { The knowledge about the prevalence of } \\
\text { supernumerary teeth and variations in anatomy and } \\
\text { the number of root canals aid in easy identification } \\
\text { of deceased person in forensics }\end{array}$ & 147 & 48.0 & 159 & 52.0 \\
\hline 10 & $\begin{array}{l}\text { Which of the following is the most advanced } \\
\text { radiographic technique to study root canal } \\
\text { complexity? }\end{array}$ & 29 & 9.5 & 277 & 90.5 \\
\hline 11 & $\begin{array}{l}\text { What is the most accurate measure that estimates } \\
\text { chronological age of patient }\end{array}$ & 170 & 55.6 & 136 & 44.4 \\
\hline 12 & $\begin{array}{l}\text { Which tooth is commonly used to calculate pulp to } \\
\text { tooth volume or area ratio when full set of teeth is } \\
\text { present? }\end{array}$ & 194 & 63.4 & 112 & 36.6 \\
\hline 13 & $\begin{array}{l}\text { Do you think human DNA still exists in the tooth } \\
\text { even after pulp extirpation is done? }\end{array}$ & 91 & 29.7 & 215 & 70.3 \\
\hline 14 & $\begin{array}{l}\text { Which tissues among the following tissues can be } \\
\text { used to obtain the pulpal DNA after complete pulp } \\
\text { extirpation? }\end{array}$ & 121 & 39.5 & 185 & 60.5 \\
\hline 15 & $\begin{array}{l}\text { What is the maximum time duration for existence of } \\
\text { DNA after pulp extirpation? }\end{array}$ & 182 & 59.5 & 124 & 40.5 \\
\hline 16 & $\begin{array}{l}\text { Which of the following methods is most commonly } \\
\text { used for amplification of highly degraded DNA? }\end{array}$ & 123 & 40.2 & 183 & 59.8 \\
\hline 17 & $\begin{array}{c}\text { Separated files Can sustain higher temperatures. Do } \\
\text { You Agree? }\end{array}$ & 203 & 66.3 & 103 & 33.7 \\
\hline 18 & $\begin{array}{l}\text { Which of the below mentioned instruments have the } \\
\text { ability of forming a glacier Layer when exposed to } \\
\text { higher temperatures? }\end{array}$ & 126 & 41.2 & 180 & 58.8 \\
\hline 19 & $\begin{array}{c}\text { There are certain materials like gutta-percha and } \\
\text { zinc oxide eugenol which are unstable above } 800 \\
\text { degree Celsius, which may lead to melting and filling } \\
\text { of missed canals. Do you agree? }\end{array}$ & 160 & 52.3 & 146 & 47.7 \\
\hline 20 & $\begin{array}{l}\text { Is storing and updating dental records really } \\
\text { necessary for legal reasons? }\end{array}$ & 41 & 13.4 & 265 & 86.6 \\
\hline & $\begin{array}{l}\text { Percentages and Frequencies of the Right c } \\
\text { for each Question }\end{array}$ & 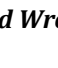 & $y$ & & \\
\hline
\end{tabular}

The practice of forensic odontology has gained tremendous importance in a number of developed countries across the world. Every year many people die due to natural disasters, where they remain unidentified. And in such situations forensic odontology plays a very important role. The death toll in India due to many natural disasters was left unanswered when the identity of the deceased is questioned.[5] Many victims of such mass disasters remain unidentified leading to major disappointment and resent for the family members and close relatives. This issue could be addressed with the identification of the deceased even when very minimal and small traces of the body parts are available. Forensic odontology is one such specialty which becomes important in such instances.

Forensic dental identification depends mainly on the recognition of common features by comparison of ante- mortem and post-mortem dental records with no contradictory differences demonstrated between the two sets of records. The vital role of forensic odontology in identification is based on the unique characteristics and disposition of the teeth of different individuals. Although establishment of individual identity by the use of forensic odontology has been extremely useful and reliable, it is totally dependent on the presence of ante-mortem records.[4]

Human dentition has myriad of variations in root canal anatomy. Therefore, an endodontist a person who has knowledge of different root canal variations, coronal pulp chamber morphology, the number and location of canals, canal lengths and canal morphology all of which aid in better identification of person.[4] Any variability in canals like number of canals, c-shaped canals, aberrant canals will contribute in personal identification when any such identification problem arises.

Innumerable radiological techniques can be utilized as an aid in human identification, including the determination of sex, ethnic group and mainly age.[8] Dental radiology has played a key role in the identification of victims in many cases. The identification of American victims of Operation Desert Storm was largely dependent on forensic dental radiology. 244 out of the 251 victims were identified based on the availability of dental records including panoramic radiographic images.[9]

Forensic scientists have been using the decrease in size of the pulp chamber for a long time as an important marker for identifying the chronological age of individuals which can be assessed by measuring pulp-tooth volume ratio using CBCT. The analysis of the volumes of the pulp chamber and the tooth is more reliable than the calculation of areas, possibly because secondary dentin formation may not be uniform along all pulp surfaces.[1] The present study showed that $55.6 \%$ of participants did not know the accurate method to estimate chronological age of deceased person.

The dental patterns are unique for every individual. This uniqueness is also true due to variety of treatments and the restorative materials used by the dentist.[10] Certain properties of endodontic instruments and materials may help in easier identification of the deceased individual. A glacier-like surface coating was observed on the nickel-titanium (Ni-Ti) composed of titanium when $\mathrm{Ni}$-Ti files are exposed to elevated temperatures within the root canal system.[1] Any broken file in the root canal space can also help in personal identification.

Intracoronal restorations, such as amalgam and resin composite fillings, can also maintain their integrity at elevated temperatures.[1] The physical changes in endodontically treated teeth in materials after their exposition to high temperatures of up to $1000^{\circ} \mathrm{C}$ showed that dental tissues and materials offer great resistance to high temperatures. This survey showed that about $47.1 \%$ of the participants did not know the maximum temperature change sustained by amalgam and composites.

However, at temperatures above $800^{\circ} \mathrm{C}$, endodontic materials like gutta-percha, zinc oxide eugenol and gutta-percha, resin cement combinations tend to change to chalk-like whitish hue, which is difficult to recognize from the incinerated dentin. [1] Materials like gutta-percha and zinc oxide eugenol which are unstable above 800 degree Celsius, lead to melting and filling of the missed canals. 
DNA analysis is a new tool used in the field of forensic odontology, which has gained importance because conventional identification methods fail due to the effects of heat, traumatism or autolytic processes, distortions, and difficulties in analysis.In such cases, pulp tissue can be used as a source of DNA.[2] The DNA profile tests are reliable and provide information about the physical characteristics, ethnicity, place of origin, and sex of the person. The present study showed that only $40 \%$ of the total participants were aware of the maximum time duration for existence of DNA after pulp extirpation and $61 \%$ of them were aware that dentinal tubules still retain pulpal DNA after pulp extirpation.

There has been radical increase in act of terrorism in recent years and criminals are finding newer ways to get away with the offence. Hence newer techniques are essential to bring the culprits to book and provide justice to the victims. In this aspect the branch of forensic odontology can help the investigating officers in a number of cases and variety of situations. [11] But forensic odontology solely cannot identify the victim, multidisciplinary approach is indispensable.

Specialization in forensic odontology has been possible in several countries around the world, but while the Dental Council of India has included this as a subject in the BDS. Course Regulations (2007), a postgraduate course is yet to be started. [11] Every contact leaves traces. [12] Therefore importance of forensic odontology should be included in academics for post graduate students. Periodic conferences, workshops, CDEs, and seminars if conducted, will help to enrich the knowledge and awareness. [13]

\section{CONCLUSIONS}

The results of the present survey revealed that $6 \%$ of total participants had good awareness ( $>16$ Qs), $62 \%$ of total participants showed moderate awareness (10-16 Qs) and $32 \%$ of total participants had poor awareness $(<10$ Qs). By considering the present expansion in the field of forensic odontology, endodontists should be knowledgeable of the role of their specialization in forensic odontology.

\section{REFERENCES}

[1] Ahmed HMA. Endodontics and forensic personal identification: an update. Eur J Gen Dent 2017;6(1):5-8.

[2] Hegde P, Shetty S, Gupta L. Role and importance of forensic odontology in identification. Int Interdiscip J Sci Res 2014;1(3):64-9.

[3] Acharya AB. A decade of forensic odontology in India. J Forensic Dent Sci 2010;2(1):1.

[4] Bansode PV, Pathal SD, Wavdhane MB, et al. Application of endodontic imaging modalities in forensic personal identification: a review. IOSR Journal of Dental and Medical Sciences (IOSR-JDMS) 2018;17(4):45-8.

[5] Preethi S, Einstein A, Sivapathasundharam B. Awareness of forensic odontology among dental practitioners in Chennai: a knowledge, attitude, practice study. J Forensic Dent Sci 2011;3(2):63-6.

[6] Savio C, Merlati G, Danesino P, et al. Radiographic evaluation of teeth subjected to high temperatures: experimental study to aid identification processes. Forensic Sci Int 2006;158(2-3):108-16.

[7] Pinchi V, Torricelli F, Nutini AL, et al. Techniques of dental DNA extraction: some operative experiences. Forensic Sci Int 2011;204(1-3):111-4.

[8] Carvalho SP, Silva RH, Lopes C Jr, et al. Use of images for human identification in forensic dentistry. Radiol Bras 2009;42(2):125-30.

[9] Kessler HP, Pemble CW 3rd. Forensic dental identification of casualties during Operation Desert Storm. Mil Med 1993;158(6):359-62.

[10] Jeddy N, Ravi S, Radhika T. Current trends in forensic odontology. J Forensic Dent Sci 2017;9(3):115-9.

[11] Navya N, Raj JD. To assess the knowledge and attitude toward forensic odontology among dentists in Chennai city. Int J Forensic Odontol 2016;1(1):17-20.

[12] Sumalatha S, Padmaja S, Thumati P. Every contact leaves its trace - insight into recent advances of forensic odontology. J Cancer Treat Res 2015;3(1):1-7.

[13] Sahni A, Rehani S, Mathias Y, et al. A questionnaire survey on forensic odontology: Are we really aware? J Forensic Dent Sci 2016;8(2):113. 